\title{
Visual performance: validation of the inventory of visual efficiency in students
}

\author{
Desempenho visual: validação do inventário \\ de eficiência visual em estudantes
}

Amélia Fernandes Nunes ${ }^{1}$ António João Santos Nunes² Pedro Miguel Lourenço Monteiro' Maria Assunção Morais Vaz Pato ${ }^{3}$

\begin{abstract}
Purpose: Translate and adapt the COVD-QoL questionnaire to Portuguese language and culture and assess the psychometric properties of the translated questionnaire. Methods: The questionnaire was adapted according to the methodology recommended by the literature. The final version of visual symptoms and quality of life questionnaire adapted to Portuguese (QSL-QOL) was applied in 130 volunteers, aged 18 to 30 years and 36 subjects completed the questionnaire at two different times. Results: The results showed good internal consistency for the full version with 30 items $(\alpha=0.894)$ and for the short version with 19 items $(0.858)$. The test re-test revealed an average of differences between the first and second evaluation of 0,917 points $(\mathrm{SD}= \pm 4.813)$ which indicates a minimum bias between the two applications. Conclusions: The Portuguese version of COVD-QoL showed good psychometric properties and has been shown to be applicable to the Portuguese population, to evaluate visual discomfort associated with near vision in higher education students.
\end{abstract}

Keywords: Vison disorders; Life quality; Optometry/methods; Vision tests/standards; Questionnaires; Students

\section{RESUMO}

Objetivo: Traduzir e adaptar transculturalmente o questionário COVD-QoL para a língua portuguesa e avaliar as propriedades psicométricas do questionário traduzido. Métodos: O questionário foi adaptado segundo a metodologia recomendada pela literatura. A versão final do questionário de sintomas e eficiência visual adaptado à língua portuguesa (IEV - Inventário de eficiência visual) foi aplicada em 130 indivíduos, com idades compreendidas entre os 18 e os 30 anos e 36 sujeitos responderam ao questionário em dois momentos distintos. Resultados: Os resultados evidenciam uma boa consistência interna tanto para a versão completa, com 30 itens ( $\alpha$ $=0,894)$ como para a versão curta, com 19 itens $(0,858)$. O teste reteste revelou uma média de diferenças entre a primeira e a segunda

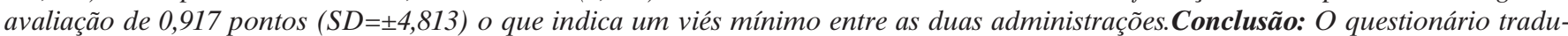
zido, apresentou boas propriedades psicométricas e demonstrou ser aplicável à população portuguesa, para se avaliar a eficiência visual associada à visão de perto, em estudantes do ensino superior.

Descritores: Transtornos da visão; Optometria/métodos; Qualidade de vida; Testes visuais/normas; Questionários; Estudantes

\footnotetext{
1 Remote Sensing Unit, Department of Physics, Beira Interior University, Covilhã, Portugal.

${ }^{2}$ NECE Research Center, Management andEconomics Department, Beira Interior University, Covilhã, Portugal.

${ }^{3}$ Health Science Research Centre, FCS-UBI. Portugal; Guarda Local Health Unit, Hospital Sousa Martins, Guarda, Portugal.
}

The authors declare no conflict of interest.

Received for publication 13/08/2014 - Accepted for publication 22/09/2014

Rev Bras Oftalmol. 2015; 74 (2): 92-8 


\section{INTRODUCTION}

$\mathbf{T}$ The growing demands of working with near vision, both quantitative and qualitative, such as reading from a computer screen or paper, continuously and routinely, can cause several disorders related mainly to excessive use of vision, but also to a growing general physical and mental stress. Asthenopia, or eye strain, is caused by a constant effort by the visual system to accommodate and adjust vision to every visual demand.

Among several ocular alterations, cataract and binocular vision disorders are considered the most frequent and have a significant negative impact on the quality of life of afflicted people. Reestablishing a proper relation between acommodation and binocularity is crucial to reduce eye strain, contributing to a greater general comfort, increasing academic performance, work or even just recreation $\left({ }^{1-5}\right.$.

Literature shows several questionnaires which were designed and validated to measure symptomatology associated with visual discomfort, including: questionnaire developed by Conlon and his team(6); questionnaire about quality of life in pseudophakic patients(7), questionnaire "Convergence Insufficiency Symptom Survey - CISS (3)"; questionnaire "College of Optometrists in Vision Development Quality of Life (COVDL-QoL) (8).

The COVD-QoL questionnaire, developed by COVD College of Optometrists in Vision Development, quoted by several investigators and copied, in part or as a whole $e^{(5,8-11)}$, is noted for its simplicity and reliability in results of ocular alteration assessments, which jeopardize study or work performance, and therefore points to people who need visual attention by experts on visual health( $(4,8-12)$.

Due to the lack of auto-completion tools in Portugal that have good reproducibility rates and can be easily applied to assess visual discomfort associated with near vision tasks, the main goal of this study is to adapt the COVDL-QoL questionnaire to the Portuguese language and culture. It will be named "Inventory of Visual Efficiency (IEV)."

\section{Methods}

The study occurred at the Vision Science Laboratory at Beira Interior University, approved by the ethics committee of the Health Sciences Program of the same university (file CEFCS-2012-027). There were two phases to the investigation: phase one included the translation and cross-cultural adaptation to Portuguese and phase two was the psychometric validation of the questionnaire.

The translation and cross-cultural adaptation was based on guidelines suggested by the Beaton and Gjersing teams $(13,14)$.

The psychometric validation of the translated questionnaire was obtained by inter-item internal consistency analysis, as well as assessment of temporal stability and reproducibility, through test and retest. For desired results, the questionnaire was applied twice, by two different investigators. The temporal interval between both application moments respected a long enough period so that no significant alterations in general behavior of patients would be expected, nor would it be likely to remind them of answers given in the first application.This interval was a week long, a period of time suggested by literature to analyze the reliability of a measuring instrument for health status in test-retest. 15.

\section{Participants:}

15 students from the Health Sciences Program participated in the process of translating and adapting the questionnaire (pretest). In the psychometric validation phase, 130 students participated, with ages ranging from 18 to 30 years old. Of 130 participants, 36 repeated the questionnaire a week later. All participants were informed about the objective of the study and signed the free, informed and clear consent form, according to theHelsinkideclaration.

\section{Instrument}

The instrument under study was the COVDL-QoL questionnaire, which assesses the impact of visual deficits not only on a visual function level, but also on other activities to which vision is strongly linked, and that is why we will name it Inventory of Visual Efficiency (IEV). IEV discusses symptoms which are usual in vision anomalies associated with four quality of life categories: somatic, physical/occupational, social and psychological(8). It is an instrument composed of 30 questions which assess the existence and frequency of symptoms associated with visual and perceptive abilities which hinder visual performance (Attachment 1).In each question, the subject indicates the frequency in which each symptom occurs on a likert scale that is scored zero to four, where zero means "never", one means "rarely", two means "sometimes", three means "often" and four means "always". The answers to all 30 items are added for the final score. A score higher than 17 indicates the possibility of visual alteration and suggests the need for a more in-depth examination $(8,9)$.

\section{Procedures}

Before translation and validation, the questionnaire was requested with digital support and written authorization from the institution which developed the original questionnaire. Once the authorization was obtained, and after obtaining a favorable decision from the ethics committee to undertake the study with students from the Beira Interior University, we moved on to apply the work instrument described next.

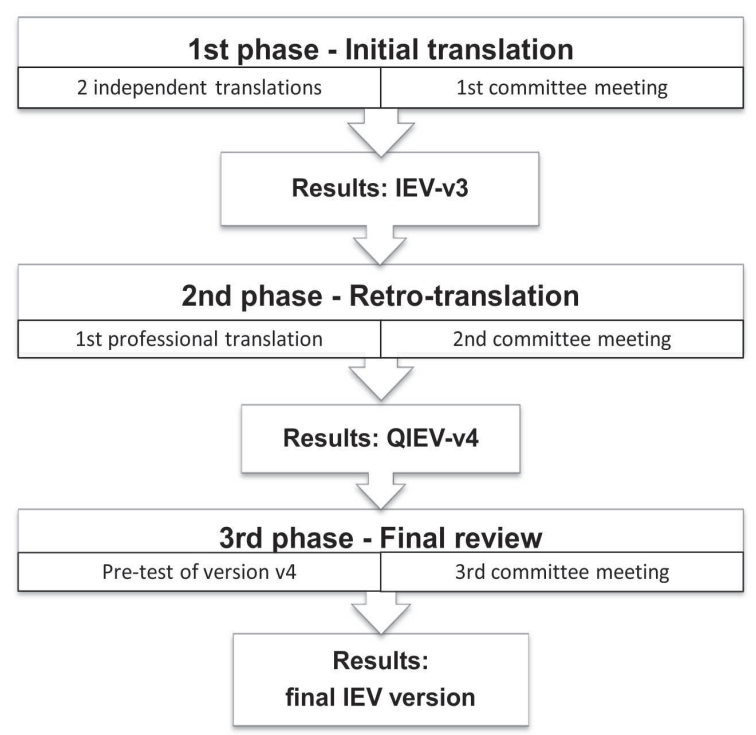

Figure 1: Phases of translation and adaptation of the COVD-QoL questionnaire into Portuguese (IEV). 


\section{Translation and cross-cultural adaptation process}

The methodology procedures suggested by Beaton and Gjersing $(13,14)$ were used to translate and adapt the questionnaire from its original language, English, into the target language, Portuguese, so as to obtain a translation and cross-cultural validation supported on a scientific basis. The process occurred in three phases, from the initial COVQ-QoL translation to the final IEV Portuguese version, as can be seen in the figure1 organogram.

Initial translation: In this phase, two independent translations were created ( $\mathrm{v} 1$ and $\mathrm{v} 2$ ) by two bilingual translators from two entirely different areas. At the first assessment meeting, a committee composed of two visual health professionals, a social sciences professor, a neurologist and the two independent translators discussed the translations (v1 and v2) in depth, comparing them to the original questionnaire as well. The outcome of the meeting was a third translated version of the questionnaire, with consensus among all those present (v3).

Retro-translation: In this phase, version v3 of the visual symptoms questionnaire translated into Portuguese was translated again into its original language (English) by a professional translator, without showing him the original version, and that is the retrotranslated version. A meeting was held after obtaining the retrotranslated version, which was attended by the same committee from the first meeting and the professional translator. At this meeting, the original questionnaire (COVD-QoL), the translated IEV-v3 questionnaire and the retro-translated questionnaire were analyzed, set against each other and assessed, causing small syntax alterations that became a new version 4 (IEV-v4).

Final review: In this phase a pre-test was carried out by applying version IEV-v3 of the translated questionnaire to 15 university students, to determine whether there were difficulties in understanding and interpreting content from different items. The option "I don't understand the question" was added to the set of answers for each item. Volunteers were also asked to make comments about questions which caused them doubts. After analyzing the results of this pre-test, the final layoutof the Inventory of Visual Efficiency (IEV) in Portuguese was created.

\section{Statistical treatment:}

All statistical procedures were performed with the statistics software IBM SPSS Statistics version 20.

The scale reliability of a measuring instrument built by a Likert scale is assessed by the Cronbach coefficient a. This coefficient assesses the internal consistency of a set of items, that is, it states whether the answers are coherent enough (in relation to themselves), so as to conclude that they are all measuring the same parameter and can all be added to a single score. Ratings higher than 0.7 are considered acceptable and lower than 0.6 are considered unacceptable ${ }^{(16)}$.

The reliability of the measuring instrumentwas studied through several tests. The Spearman correlation coefficient assesses the connection of the questionnaire score between both assessment times, to determine temporal stability, and the intraclass correlation coefficient (ICC) determines the degree of consistency of measurements made by different evaluators. The ICC interpretation was based on Bland's suggestions, where ratings under 0.4 are considered unacceptable, from 0.41 to 0.6 are considered to have good reproducibility, from 0.61 to 0.80 very good reproducibility and from 0.81 to 1.0 excellent reproducibility ${ }^{(17)}$.

\section{Results}

\section{Translation and adaptation of the questionnaire:}

In the first phase of translation and adaptation to Portuguese, inconsistencies in both independent translations were discussed at the first meeting and corrected through consensus among members of the committee.

\section{The second phase also went smoothly.}

In the third phase, the results of the pre-test application showed no difficulties in interpreting any of the items of the translated questionnaire. The result of the entire process, which is in attachment $\mathrm{A}$, is the layoutof the final version of the questionnaire in its Portuguese version.

\section{Psychometric validation:}

To validate the translation of the measuring instrument, answers were analyzed in the complete questionnaire, with 30 items, and in their short version, with 19 items ${ }^{(8,12)}$. Each dimension of the full questionnaire was also analyzed individually: somatic, physical/occupational, social and psychological dimensions. Researchers studied the differences in average score at two different moments, set apart by a week, and the internal consistency of the scale was assessed.

The internal consistency of the inventory, both in its full version and its short one, show a moderate to high level of reliability (Table 1 ).

The analysis of total internal consistency, and whether an item should be eliminated, shows that all items contribute to a greater consistency. However, item 17 may be discussed and possibly excluded from the inventory without reducing its total consistency(Tabela 2). Its elimination does not contribute to a significant increase in internal consistency, though. Besides, since this is a translation and adaptation of a measuringinstrument into a new language, maintaining these items may be useful in future comparisons with data from other populations and cultures. Cronbach's alpha for the instrument obtained in testretest, with 36 participants, was slightly higher (0.914) than that from the first application (0.849).

The four inventory dimensions reveal acceptable reliability levels ( Table 1). However, the social dimension shows a lower internal consistency, so if the instrument is going to be only partially applied, it is better that this dimension is not applied separately from the others.

\section{IEV Reliability Analysis}

Temporal reliability was measured by a test-retest analysis, by estimating the Spearman correlation between the score of each item in each assessment. Check table 3 to see Spearman's rho coefficient item per item and for the total score.

All items showed significant correlation to the level of 0.001 , except for items 12 and 13 which showed significant correlation to 0.05 . Table 3 shows that the correlation coefficients of answers given to items between the first and second application vary between 0.421 (Item 12) e 0.861 (Item 9). According to Maroco, correlations may be considered high between 0.70 and 0.89 and moderate between 0.4 and ${ }^{0.69}(18)$. Total scores obtained in both phases of questionnaire application have excellent correlation (0.917). 
Table 1

Descriptive statistics: age of volunteers, total score and internal consistency of the IEV instrument in its full version (30 items) and its short version (19 items).

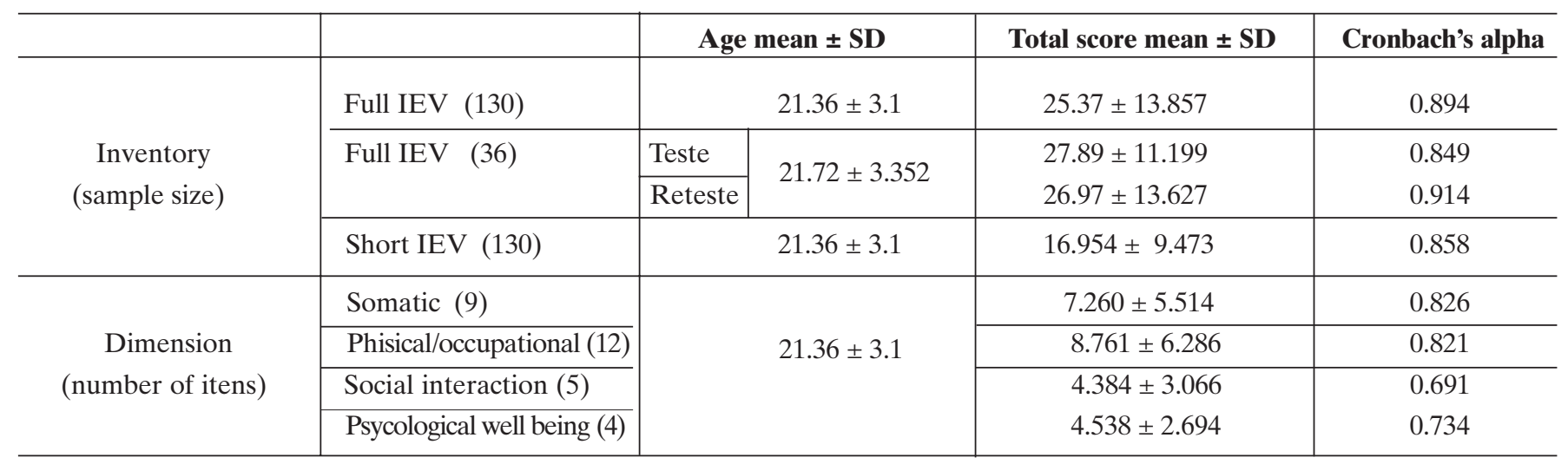

Table 2

Reliability: internal consistency of the IEV Portuguese version

\begin{tabular}{|c|c|c|c|c|c|}
\hline Item & $\begin{array}{l}\text { Corrected item- } \\
\text { total correlation }\end{array}$ & $\begin{array}{l}\text { Cronbach's alpha if the } \\
\text { item were eliminated }\end{array}$ & Item & $\begin{array}{l}\text { Corrected item- } \\
\text { total correlation }\end{array}$ & $\begin{array}{l}\text { Cronbach's alpha if the } \\
\text { item were eliminated }\end{array}$ \\
\hline 1 & 0.530 & 0.889 & 16 & 0.514 & 0.890 \\
\hline 3 & 0.568 & 0.888 & 18 & 0.292 & 0.894 \\
\hline 4 & 0.550 & 0.889 & 19 & 0.648 & 0.887 \\
\hline 6 & 0.445 & 0.891 & 21 & 0.319 & 0.893 \\
\hline 7 & 0.509 & 0.889 & 22 & 0.317 & 0.893 \\
\hline 8 & 0.585 & 0.888 & 23 & 0.318 & 0.893 \\
\hline 9 & 0.436 & 0.891 & 24 & 0.630 & 0.887 \\
\hline 10 & 0.402 & 0.892 & 25 & 0.490 & 0.890 \\
\hline 14 & 0.426 & 0.891 & 29 & 0.310 & 0.894 \\
\hline 15 & 0.517 & 0.889 & 30 & 0.531 & 0.889 \\
\hline
\end{tabular}

Table 3

Spearman correlation coefficient between test and retest

\begin{tabular}{lccccccccccc}
\hline Item & $\mathbf{1}$ & $\mathbf{2}$ & $\mathbf{3}$ & $\mathbf{4}$ & $\mathbf{5}$ & $\mathbf{6}$ & $\mathbf{7}$ & $\mathbf{8}$ & $\mathbf{9}$ & $\mathbf{1 0}$ \\
\hline Rho & 0.664 & 0.772 & 0.640 & 0.722 & 0.780 & 0.62 & 0.797 & 0.471 & 0.861 & 0.654 \\
\hline Item & $\mathbf{1 1}$ & $\mathbf{1 2}$ & $\mathbf{1 3}$ & $\mathbf{1 4}$ & $\mathbf{1 5}$ & $\mathbf{1 6}$ & $\mathbf{1 7}$ & $\mathbf{1 8}$ & $\mathbf{1 9}$ & $\mathbf{2 0}$ \\
\hline Rho & 0.841 & 0.421 & 0.423 & 0.716 & 0.538 & 0.636 & 0.526 & 0.731 & 0.650 & 0.514 \\
\hline Item & $\mathbf{2 1}$ & $\mathbf{2 2}$ & $\mathbf{2 3}$ & $\mathbf{2 4}$ & $\mathbf{2 5}$ & $\mathbf{2 6}$ & $\mathbf{2 7}$ & $\mathbf{2 8}$ & $\mathbf{2 9}$ & $\mathbf{3 0}$ \\
\hline Rho & 0.495 & 0.547 & 0.565 & 0.672 & 0.719 & 0.500 & 0.781 & 0.717 & 0.742 & 0.764 \\
\hline
\end{tabular}

Total score: $r h o=0.917$ 
The intraclass correlation coefficient (ICC) for both assessment moments was 0.926 (95\% IC: 0.859 e 0.951$)$. The retest test revealed an average of differences between the first and second evaluation of 0.917 points $(\mathrm{SD}= \pm 4.813)$ which indicates a minimum bias between the two applications(sign test: $\mathrm{z}=-1.200 ; \mathrm{p}=0.230)$.

\section{Discussion}

The results of the study indicate that the translation and adaptation of the COVD-QoL questionnaire into Portuguese, which resulted in the Inventory of Visual Efficiency (IEV) version, represents a reliable measuring instrument when applied to university students. The high internal consistency of answers obtained with the questionnaire $(\mathrm{a}=0.894)$ and the high intraclass correlation $(\mathrm{ICC}=0.926)$ both indicate that the IEV Portuguese version has a high level of reliability.

The translation and adaptation process was based on respect for scientific rigour, following the most recognized guidelines in similar studies 13,14$)$. Using two independent translators proved to be a useful decision, because it allowed for the discussion of two different versions that did not know each other. The result was the creation of a single translation that overcame initial differences. The inclusion of members from different areas of knowledge in the assessment committee allowed the inclusion of several opinions from experts from the healthcare sector as well as from the social sciences sector. The discussions about differences found in the translations and the search for consensual solutions turned out to be crucial for the entire semantic equivalence process. The pre-test applied in phase 3 made it clear that all participants understood the questions of instrument IEV.

In the psychometric validation of the scale, the inter-item internal consistency analysis through Cronbach's alpha coefficient showed results of 0.914 and 0.849 , indicating that IEV's internal consistency is high, whether it is applied in its full or short version(16).

The correlation between each item in both assessment times shows that some items have a high correlation, while others have a more moderate correlation, however, the total score of the questionnaire shows a high correlation between test and retest (0.917), which allows us to conclude that the Portuguese questionnaire shows good temporal reliability. This data matches the results found in the reliability studies for the original questionnaire $(8,12)$.

The ICC coefficient was 0.926 , which shows that the IEV has excellent reproducibility (17). The mean difference $(0.917 \pm 4.813)$, as well as the variance analysis between both assessment times (sign test: $\mathrm{z}=-1.200 ; \mathrm{p}=0.230$ ) show a minimum bias between both applications, which occurred within a week of each other.

Assessing the impact of specific pathologies on quality of life is a crucial step to be able to define strategies and assess the effects of potential treatments $\left({ }^{1-5)}\right.$. The multidimensionality of the IEV questionnaire, its easy applicability and interpretation allow it to be used for the most diverse types of ocular alterations that affect the ability to carry out normal activities in their daily lives.

Cataracts, which are a serious healthcare issue in many countries, are an important challenge, and it is hard to understand how it reduces quality of life in people and to identify the benefits of its treatment in the improvement of their quality of life $\left(1,7,{ }^{19}\right)$.
The functional vision assessment of patients with cataracts, aided by this inventory, will be able to understand the impact on the four categories of quality of life: somatic, physical/occupational, social and psychological, since some patients can adapt to visual impairment without noticing their functional decline $\left.{ }^{(7,20.21}\right)$.

The capital gains of this questionnaire, which has been applied (4) in therapy follow-ups and in assessing the effect of rehabilitation of ocular conditions, can also be used in describing how different stages of cataract reduce quality of life in people and in the identification of benefits from its treatment in improving this quality of life, assessing post-surgery improvement with the use of multifocal IOLs $(1,2,19)$.

It has to be said that the questionnaire has been applied mostly to children, teenagers and young adults $\left({ }^{4,5,8-12)}\right.$, so some of the items may not be applicable to the elderly population. The elimination of some of those items does not significantly alter the reliability of the psychometric results. The internal consistency of the questionnaire remains high even when some of the questions are eliminated.

\section{Conclusion}

Considering the main objective of this study: the translation of the symptoms and visual efficiency questionnaire (COVDQoL) into Portuguese (IEV), the objective has been achieved, showing psychometric features which are very promising in its application.

The measuring scale had internal reliability levels (Cronbach's alpha) and temporal stability levels (test-retest) between very good and excellent, proving to be a reliable and reproducible instrument. It is important to state that the adaptation of the questionnaire was applied to university students.

Finally, for proper use of the questionnaire as an instrument of visual screening among students, other steps of the validation process must be followed, namely the studies of its sensitivity and specificity.

\section{References}

1. de Santhiago MR, Netto MV, Espindola RF, Mazurek MG, Gomes $\mathrm{BD}$, Parede TR, et al. Comparison of reading performance after bilateral implantation of multifocal intraocular lenses with +3.00 or+ 4.00 diopter addition. J Cataract Refrat Surg. 2010; 36(11):1874- 9.

2. Hida WT, Motta AF, Kara-José Jr N, Costa H, Tokunaga C, Cordeiro LN, et al. Estudo comparativo do desempenho visual e análise de frente de onda entre as lentes intra-oculares multifocais difrativas Tecnis ${ }^{\circledR}$ ZM900 e AcrySof ${ }^{\circledR}$ ReSTOR ${ }^{\circledR}$ SN60D3. Arq Bras Oftalmol. 2008; 71(6):788-92.

3. Borsting E, Rouse MW, De Land PN. Prospective comparison of convergence insufficiency and normal binocular children on CIRS symptom surveys. Convergence Insufficiency and Reading Study (CIRS) group. Optom Vis Sci. 1999; 76(4):221-8.

4. Daugherty KM, Frantz KA, Allison CL, Gabriel HM. Evaluating changes in quality of life after vision therapy using the COVD Quality of Life Outcomes Assessment. Optom Vis Dev. 2007; 38:75-81.

5. Shin HS, Park SC, Park CM. Relationship between accommodative and vergence dysfunctions and academic achievement for primary school children. Ophthalmic Physiol Optics. 2009;29(6):615-24. 
6. Conlon E, Lovegrove W, Chekaluk E, Pattison P. Measuring visual discomfort. Vis Cogn. 1999; 6(6):637-66.

7. Hida WT, Nakano CT, Yamane I, Motta AF, Tzeliks PF, Guimaraes AS, et al. Elaboração e validação do questionário de satisfação dos pacientes pseudofácicos em português. Rev Bras Oftalmol. 2013;72(6):388-95.

8. Maples WC. Test-retest reliability of the college of optometrists in vision development quality of life outcomes assessment. Optometry. 2000;71(9):579-85.

9. Vaughn W, Maples WC, Hoenes R. The association between vision quality of life and academics as measured by the College of Optometrists in Vision Development Quality of Life questionnaire. Optometry. 2006; 77(3):116-23.

10. Bleything WB, Landis SL. The College of Optometrists in Vision Development-QOL questionnaire in a socially at-risk population of youth. Optometry Vis Develop. 2008; 39(2):82.

11. Abu Bakar NF, Chen AH, Rahim A, Goh PP. The use of COVDQOL Questionnaire in school vision screening. i-Perception. 2011;2(4):310.

12. Maples WC. Test-retest reliability of the college of optometrists in vision development quality of life outcomes assessment short form. J Optom Vis Dev. 2002;33:126-34.

13. Beaton DE, Bombardier C, Guillemin F,Ferraz MB. Guidelines for the process of cross-cultural adaptation of self-report measures. Spine. 2000;25(24):3186-91.

14. Gjersing L, Caplehorn JR, Clausen T. Cross-cultural adaptation of research instruments: Language, setting, time and statistical considerations. BMC Med Res Methodol. 2010;10:13.
15. Marx RG, Menezes A, Horovitz L, Jones EC, Warren RF. A comparison of two time intervals for test-retest reliability of health status instruments. J Clin Epidemiol. 2003; 56(78):30-5.

16. Cortina JM. What is coefficient alpha? an examination of theory and applications. J Appl Psychol. 1993;78:98-104.

17. Bland JM, Altman DG. A note on the use of the intraclass correlation coefficient in the evaluation of agreement between two methods of measurement. ComputBiol Med. 1990;20(5):337-40.

18. Maroco J. Análise estatística com utilização do SPSS. 3a ed. Lisboa: EdiçõesSílabo; 2007.

19. de Santhiago MR, Netto MV, Barreto Jr J, Gomes BD, Schaefer A, Kara-Junior N. A contralateral eye study comparing apodized diffrative and full diffrative lenses: wavefront analysis and distance and near uncorrected visual acuity. Clinics. 2009; 64(10): 953-60.

20. Marback R, Temporini E, Kara Júnior N. Emotional factors prior to cataract surgery. Clinics. 2007; 62(4): 433-8.

21. Temporini ER, Kara Junior N, José NK, Holzchuh N. Popular beliefs regarding the treatment of senile cataract. Rev Saúde Pública. 2002; 36(3):343-9.

\section{Correspondingauthor:}

Amélia Fernandes Nunes

Universidade da Beira Interior

Rua Marquês de Ávila e Bolama, 6201-001 Covilhã, Portugal 
Attachment 1

\section{Inventário de Eficiência Visual}

Assinale com $\mathrm{X}$ a coluna que melhor representa a frequência com que ocorre cada um dos sintomas segundo a escala

\begin{tabular}{|c|c|c|c|c|c|c|}
\hline & & $\begin{array}{l}\text { Never } \\
\mathbf{0}\end{array}$ & $\begin{array}{l}\text { Raramente } \\
\mathbf{1} \\
\end{array}$ & $\begin{array}{c}\text { Às vezes } \\
\mathbf{2} \\
\end{array}$ & $\begin{array}{c}\text { Frequentemente } \\
\mathbf{3} \\
\end{array}$ & $\begin{array}{c}\text { Sempre } \\
\mathbf{4}\end{array}$ \\
\hline 1 & Visão turva a trabalhar ao perto & 0 & 1 & 2 & 3 & 4 \\
\hline 2 & Visão dupla & 0 & 1 & 2 & 3 & 4 \\
\hline 3 & Dores de cabeça a trabalhar ao perto & 0 & 1 & 2 & 3 & 4 \\
\hline 4 & Na leitura as palavras misturam-se & 0 & 1 & 2 & 3 & 4 \\
\hline 5 & Ardor, comichão e lacrimejo dos olhos & 0 & 1 & 2 & 3 & 4 \\
\hline 6 & Sonolência durante a leitura & 0 & 1 & 2 & 3 & 4 \\
\hline 7 & Vê pior no final do dia & 0 & 1 & 2 & 3 & 4 \\
\hline 8 & Salta ou repete linhas durante a leitura & 0 & 1 & 2 & 3 & 4 \\
\hline 9 & Tonturas ou náuseas quando trabalha ao perto & 0 & 1 & 2 & 3 & 4 \\
\hline 10 & Inclina a cabeça ou fecha um dos olhos durante a leitura & 0 & 1 & 2 & 3 & 4 \\
\hline 11 & Dificuldades em copiar do quadro & 0 & 1 & 2 & 3 & 4 \\
\hline 12 & Evita trabalhar e ler ao perto & 0 & 1 & 2 & 3 & 4 \\
\hline 13 & Omite palavras pequenas durante a leitura & 0 & 1 & 2 & 3 & 4 \\
\hline 14 & Escreve a subir ou a descer & 0 & 1 & 2 & 3 & 4 \\
\hline 15 & Desalinha algarismos ou colunas de números & 0 & 1 & 2 & 3 & 4 \\
\hline 16 & Dificuldade em compreender o que lê & 0 & 1 & 2 & 3 & 4 \\
\hline 17 & Prestação desportiva fraca & 0 & 1 & 2 & 3 & 4 \\
\hline 18 & Segura muito perto o material de leitura & 0 & 1 & 2 & 3 & 4 \\
\hline 19 & Dificuldade em concentrar-se na leitura & 0 & 1 & 2 & 3 & 4 \\
\hline 20 & Dificuldade em completar as tarefas a tempo & 0 & 1 & 2 & 3 & 4 \\
\hline 21 & Pensa "não consigo" antes de tentar & 0 & 1 & 2 & 3 & 4 \\
\hline 22 & Evita desportos e jogos & 0 & 1 & 2 & 3 & 4 \\
\hline 23 & Deficiente coordenação olho-mão (má caligrafia) & 0 & 1 & 2 & 3 & 4 \\
\hline 24 & Estima distâncias com pouca precisão & 0 & 1 & 2 & 3 & 4 \\
\hline 25 & Desastrado, tropeça nas coisas & 0 & 1 & 2 & 3 & 4 \\
\hline 26 & Gere mal o seu tempo & 0 & 1 & 2 & 3 & 4 \\
\hline 27 & Não realiza os trocos correctamente & 0 & 1 & 2 & 3 & 4 \\
\hline 28 & Perde coisas & 0 & 1 & 2 & 3 & 4 \\
\hline 29 & Enjoa nos transportes (viagens) & 0 & 1 & 2 & 3 & 4 \\
\hline 30 & Esquecido / memória fraca & 0 & 1 & 2 & 3 & 4 \\
\hline
\end{tabular}

Traduzido e adaptado de COVD-QoL: www.covd.org 